\title{
Student Satisfaction and Persistence: Imperative Features for Retention in Open and Distance Learning
}

\author{
Maximus Gorky Sembiring* \\ Universitas Terbuka, Indonesia
}

\begin{abstract}
This paper examines the elements of overall service quality as evidence for student satisfaction in an open and distance learning mode. It aims mainly at assessing the implementation and utilization of services as expected and experienced by students. The paper also explores the links between satisfaction and grade point average, student persistence and retention. The research was conducted at Universitas Terbuka utilizing a survey, with the data being collected randomly through a questionnaire. The population was 1,154 Universitas Terbuka graduates attending a commencement day in May 2014. Three hundred questionnaires were distributed and 218 of them were returned complete and processed. Student satisfaction was assessed by scrutinizing the dimensions of service quality: the attributes of reliability, assurance, tangibility, empathy and responsiveness. An Importance Performance Analysis and a Customer Satisfaction Index were first applied concurrently to measure student satisfaction and the level of its importance. Structural equation modelling was then used to verify the influencing features related to satisfaction with the grade point average, persistence and retention. Eight hypotheses were formed and examined, six of which were statistically validated by the analysis. It was found that empathy, responsiveness and reliability directly influenced student satisfaction; and persistence and retention were visibly affected by satisfaction.
\end{abstract}

Keywords: service quality, persistence, retention, importance performance analysis, customer satisfaction index, structural equation model

\section{Introduction}

In appraising service quality, Parasuraman, Zeithaml and Berry (1988) stated that $Q=P$ $-\mathrm{E}$, where $\mathrm{Q}$ is service quality, $\mathrm{P}$ is perception and $\mathrm{E}$ is expectation. This implies that service quality measures the difference between what customers expect from a service and their perception of the actual service encountered. Tan and Kek (2004) used this basic scheme to investigate service quality in higher education, using an enhanced service quality approach. This effort was important as many students who endeavour to earn university degrees fail to persist (Robert \& Styron, 2009) as the services delivered are below the standard (Rojas-Mendez et al., 2009) — including in the Universitas Terbuka context (Sawitri \& Sembiring, 2013; Sembiring, 2012).

\footnotetext{
* Corresponding author. Email: gorky@ut.ac.id
} 
Issues associated with persistence and/or retention as a consequence of satisfaction in the Universitas Terbuka setting are crucial for maintaining the size and growth of the student body (Universitas Terbuka, 2011). In 2011, for instance, students were expected to total 550,000 , but the targeted number fell considerably short of that goal, totalling 432,683 (Sembiring, 2014). Factors driving student satisfaction and its relation to persistence and/or retention from a service quality perspective have been examined in Australian, Italian and Malaysian universities (respectively, Brown, 2006; Petruzzellis, D'Uggento \& Romanazzi, 2006; and Arokiasamy \& Abdullah, 2012), and these studies are relevant to an Indonesian context. The aim of this study is therefore to assess the educational service quality implemented and utilized as it was expected and experienced by students. It also elucidates the links between satisfaction and grade point average (GPA), student persistence and retention.

\section{Related Literature and the Model}

The relationship between satisfaction and service quality has attracted the interest of researchers in a wide variety of disciplines (Athiyaman, 1997). In the education sector, the construct has been applied to institutions of higher education (Kitcharoen, 2004). The dimensions of service quality adopted (Parasuraman, Zeithaml \& Berry, 1988) consisted of reliability (consistency of services); assurance (the capability of the service provider); tangibility (the hardware infrastructures); empathy (a customer-centred soft environment); and responsiveness (the ability to customize contents and the delivery of services). Prior work by Ilias, Hasan and Rahman (2008) and Tileng (2013) gave confidence in applying this model to the Universitas Terbuka framework.

The origin notion for this study was service quality and satisfaction integrated with prominent constructs within student persistence and/or retention (Tinto, 1982, 1993, 1997) and student attrition (Bean, 1983, 1985). Great progress has been made in understanding the determinants of service quality, satisfaction and persistence and/or retention (Hanaysha, Abdullah \& Waroka, 2011). Mailany (2011) and Martirosyan, Saxon and Wanjohi (2014) found that evaluation of satisfaction was related to GPA results.

Students seek out universities that provide personal, unique and memorable educational experiences (Archambault, 2008), and search for programmes that will prepare them for career advancement. Some of them even expect to gain more established forthcoming jobs. By predicting those expectations, it becomes right to establish a comprehensive model by combining all possible factors in a service quality framework, satisfaction, and their links.

This inclusive model would be a tool for measuring student satisfaction and its inferences viewed from a service quality outlook - and this in turn would allow open and distance learning (ODL) institutions to change important aspects of their operations to accommodate student expectations. It might also focus on institutional directions to fulfil student needs extensively so that the universities can maintain and make progress 
on the size and growth of their student bodies. Having considered the related literature, this study now examines the conceptual framework and the basic model used in this research.

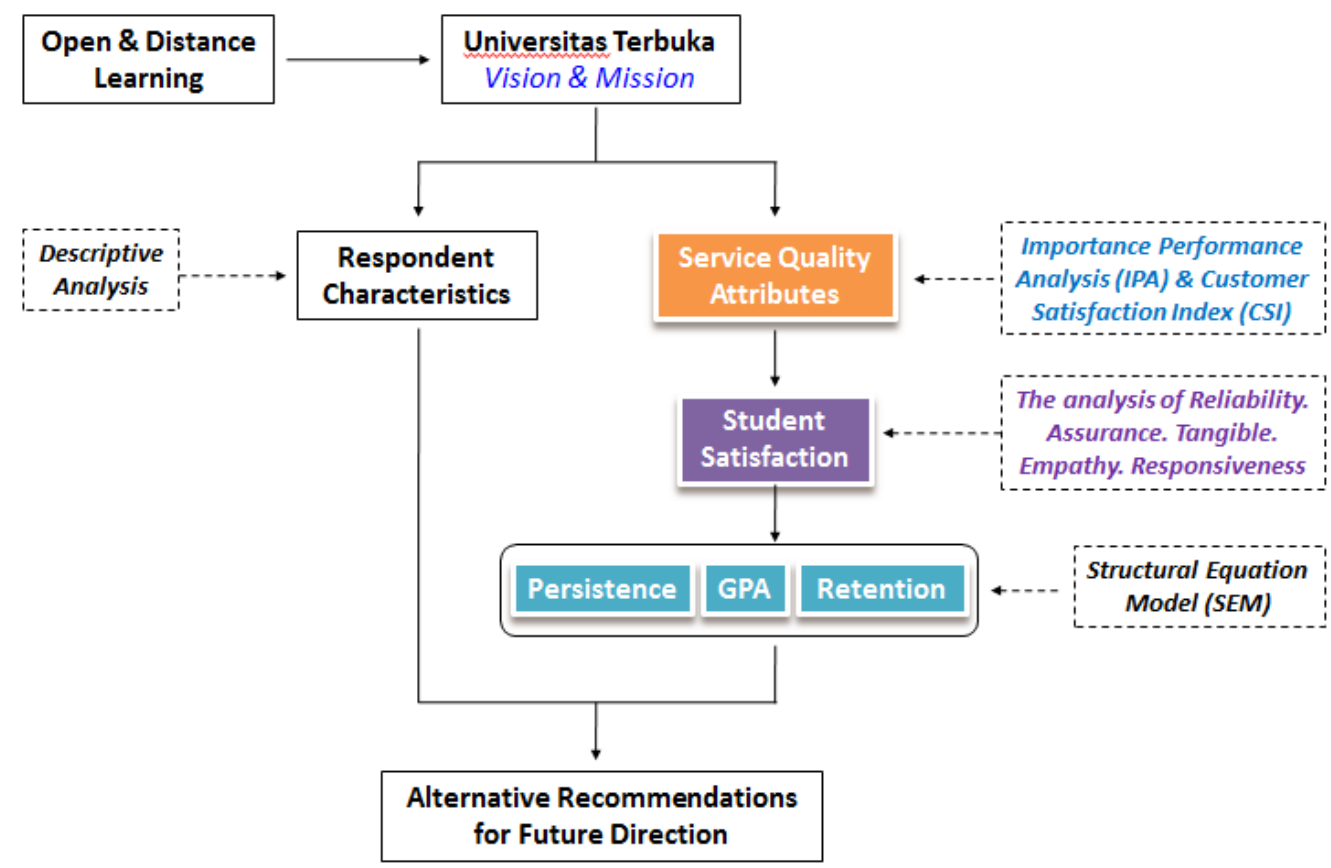

Figure 1 Conceptual framework of the research

\section{Methodology and the Hypotheses}

Figure 4 describes the features affecting student satisfaction $(\mathrm{Y})$ leading to GPA $\left(\mathrm{Y}_{6}\right)$, persistence $\left(\mathrm{Y}_{7,8,9}\right)$ and retention $\left(\mathrm{Y}_{10,11,12}\right)$. Satisfaction includes learning materials $\left(\mathrm{Y}_{1}\right)$, tutorials $\left(\mathrm{Y}_{2}\right)$, examination $\left(\mathrm{Y}_{3}\right)$, registration $\left(\mathrm{Y}_{4}\right)$ and general administration $\left(\mathrm{Y}_{5}\right)$. Satisfaction was examined by perceiving the component of service quality, including the attributes of reliability $\left(X_{1}\right)$, assurance $\left(X_{2}\right)$, tangibility $\left(X_{3}\right)$, empathy $\left(X_{4}\right)$ and responsiveness $\left(\mathrm{X}_{5}\right)$. The instruments consisted of $2 \times 25$ questions related to satisfaction and the level of its importance, plus two additional questions for assessing persistence and retention. The study utilized a quantitative approach to address the conceptual framework, the model, hypotheses, the survey and sampling, data collection and processing, and drawing the conclusions.

The variables involved were explored through a questionnaire (Tjiptono \& Chandra, 2011). A survey was implemented to collect data from respondents (Singarimbun \& Effendi, 1989). A simple random sampling technique was chosen to select eligible respondents (Sugijono, 2012). An Importance Performance Analysis (IPA) and Customer Satisfaction Index (CSI) were utilized to assess the satisfaction level, along with its importance (Kitcharoen, 2004; Silva \& Fernandez, 2010). A structural equation 
model (SEM) was used to detect probable relations among the variables (Wijayanto, 2008).

These methodological approaches examined the hypotheses $(\mathrm{H})$, which consisted of eight entries (see Figure 2), viz. satisfaction is influenced directly by reliability $\left(\mathrm{H}_{1}\right)$, assurance $\left(\mathrm{H}_{2}\right)$, tangibility $\left(\mathrm{H}_{3}\right)$ empathy $\left(\mathrm{H}_{4}\right)$ and responsiveness $\left(\mathrm{H}_{5}\right)$. GPA $\left(\mathrm{H}_{6}\right)$, persistence $\left(\mathrm{H}_{7}\right)$ and retention $\left(\mathrm{H}_{8}\right)$ are also influenced directly by satisfaction.

\section{Results and Arguments}

Before discussing the findings, it is helpful to portray the traits of the respondents as shown in Table 1, as this will enhance the perspective on the results.

Table 1 Characteristics of the respondents

\begin{tabular}{cll}
\hline No & \multicolumn{1}{c}{ Description } & \multicolumn{1}{c}{ Notes } \\
\hline 1. & Students domicile & 12 Regional Offices (out of 39) \\
\hline 2. & Population & 1,154 \\
& Minimum sample & 120 \\
\hline 3. & Questionnaires (sets) & \\
& - Provided, distributed & 300 \\
& - Returned, processed & 218 \\
\hline 4. & Grade point average & $2.00-2.49=11 \% ; 2.50-2.99=62 \% ;$ \\
& & $3.00-3.49=23 \% ; 3.50-4.00=4 \%$ \\
\hline 5. & Age (years) & $\leq 25=8 \% ; 26-30=19 \% ; 31-35=39 \%$ \\
& & $36-40=21 \% ; 41-45=11 \% ; \geq 46=2 \%$ \\
\hline 6. & Professions & Public service $=35 \% ;$ Teacher $=46 \%$ \\
& & Private sector $=4 \% ;$ Entrepreneur $=6 \% ;$ \\
& & Others $=9 \%$ \\
\hline
\end{tabular}

The results of analyses are detailed in the following explanation and figures. Figure 2 below shows that two of the hypotheses were not validated by the analysis $\left(\mathrm{H}_{2}=0.26\right.$ and $\mathrm{H}_{3}=0.95$, as the value are less than 1.96, for $\alpha=5 \%$ - which means that satisfaction is not influenced by the assurance and tangibility aspects. Conversely, the other six hypotheses are confirmed positively by the analysis - that is, satisfaction is directly influenced by reliability $\left(\mathrm{H}_{1}=2.24\right)$, empathy $\left(\mathrm{H}_{4}=2.00\right)$ and responsiveness $\left(\mathrm{H}_{5}=2.61\right)$. Moreover, GPA $\left(\mathrm{H}_{6}=2.05\right)$, persistence $\left(\mathrm{H}_{7}=10.52\right)$ and retention $\left(\mathrm{H}_{8}=\right.$ 10.36) are directly influenced by satisfaction. 


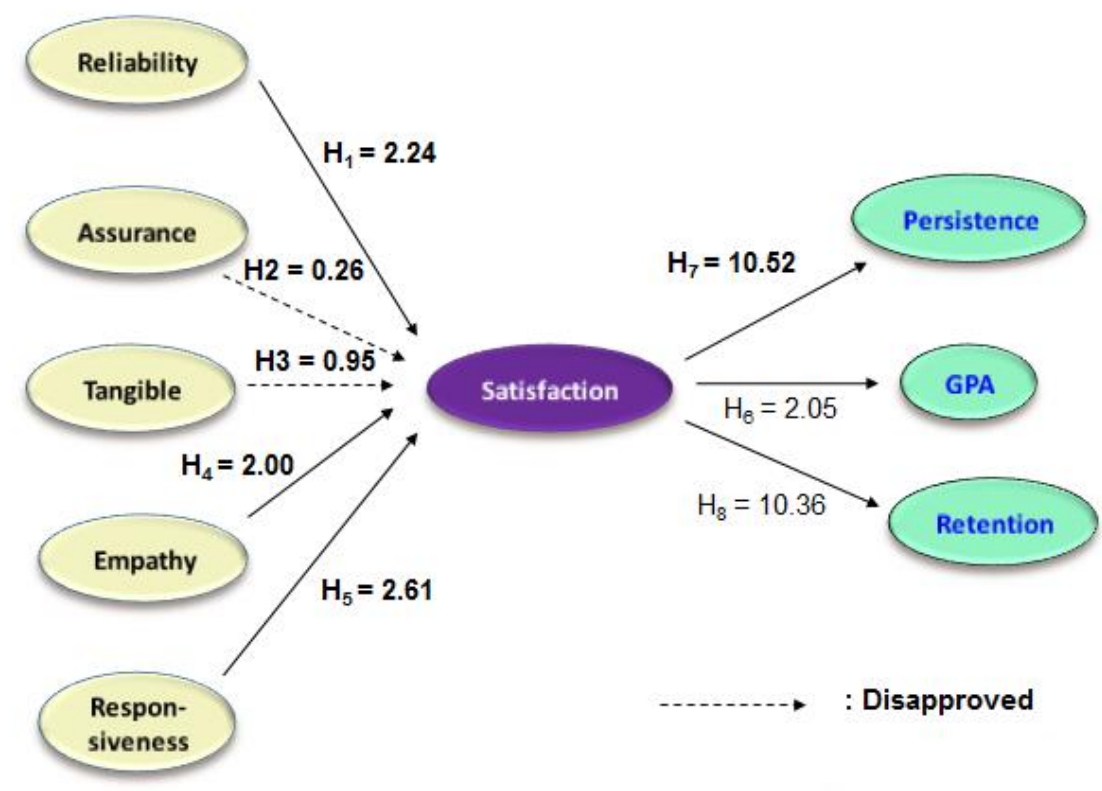

Figure 2 The $t$-value of the model

Before describing the end results, it is worth revealing the satisfaction level and the degree of its importance derived from the IPA and CSI structure. The analysis generated the position of service quality components in accordance with the related quadrants to see the degree of their importance (Figure 3).

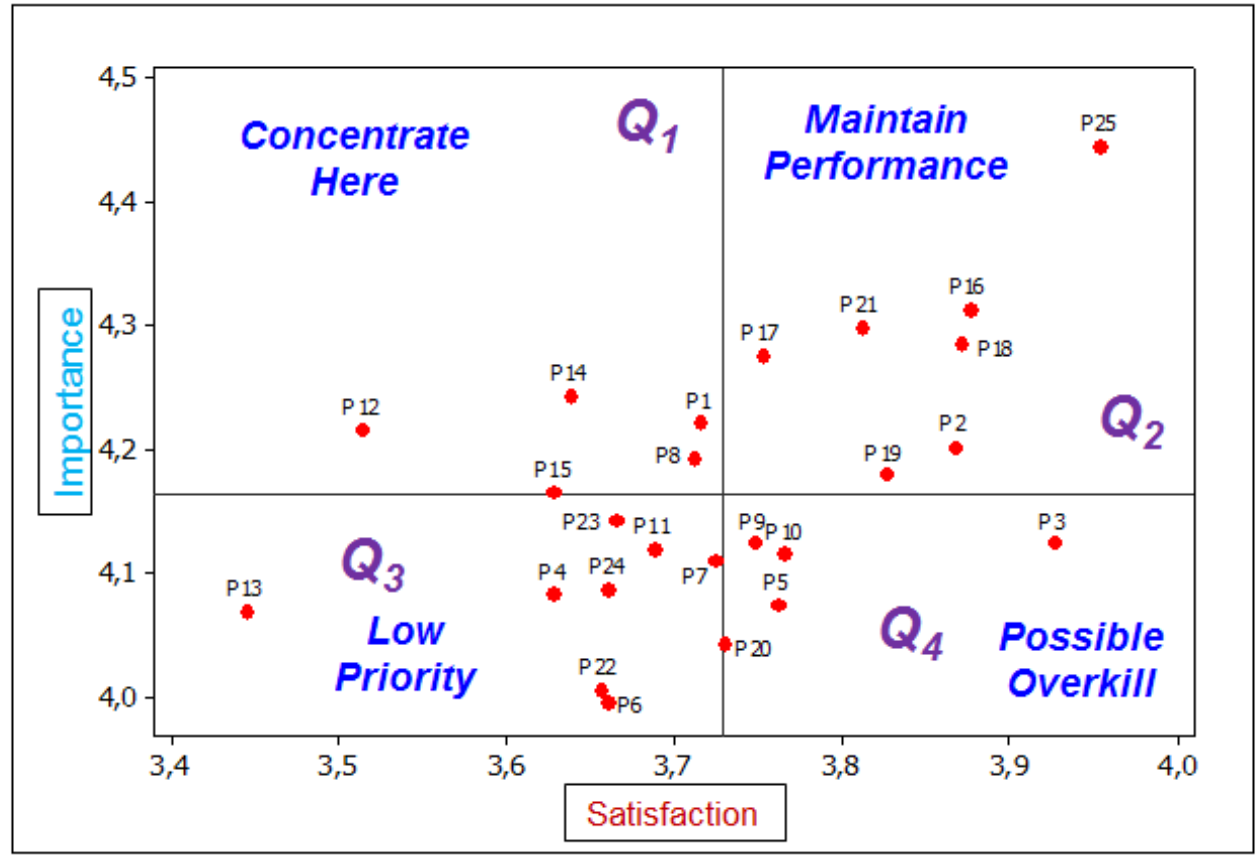

Figure 3 The IPA chart of the model 
Figure 3 has four quadrants $\left(\mathrm{Q}_{1}, \mathrm{Q}_{2}, \mathrm{Q}_{3}\right.$ and $\left.\mathrm{Q}_{4}\right)$. $\mathrm{Q}_{1}$ has five important points (Ps) that should be seriously taken into account, viz. $\mathrm{P}_{12}$ ( $\mathrm{X}_{43}$ : handling complaints), $\mathrm{P}_{15}$ ( $\mathrm{X}_{53}$ : access to management), $\mathrm{P}_{14}\left(\mathrm{X}_{52}\right.$ : communication $), \mathrm{P}_{8}\left(\mathrm{X}_{32}\right.$ : facilities $)$ and $\mathrm{P}_{1}\left(\mathrm{X}_{11}\right.$ : curriculum). 'Concentrate Here' indicates that satisfaction is at a low level whereas the degree of its importance is high. The University must pay attention to these five critical points so that student expectations can be fulfilled and they are more likely to continue and complete their studies.

$\mathrm{Q}_{2}$ includes seven points that should be recognized, viz. $\mathrm{P}_{25}\left(\mathrm{Y}_{10}\right.$ : study up to the finish), $\mathrm{P}_{16}$ ( $\mathrm{Y}_{1}$ : learning materials), $\mathrm{P}_{18}\left(\mathrm{Y}_{3}\right.$ : examination), $\mathrm{P}_{2}\left(\mathrm{X}_{12}\right.$ : relevance), $\mathrm{P}_{19}\left(\mathrm{Y}_{4}\right.$ : registration), $\mathrm{P}_{21}\left(\mathrm{Y}_{6}\right.$ : GPA), and $\mathrm{P}_{17}$ ( $\mathrm{Y}_{2}$ : tutorials). 'Maintain Performance' is a symptom of both satisfaction and the degrees of its importance being concurrently placed at a high level by the students. The University, therefore, must take care of these aspects, so that more students will get the advantage of these conditions and will pursue their studies with intent.

$\mathrm{Q}_{3}$ has eight points which should be attended to, viz. $\mathrm{P}_{13}\left(\mathrm{X}_{51}\right.$ : feedback mechanism), $\mathrm{P}_{4}$ ( $\mathrm{X}_{21}$ : student service), $\mathrm{P}_{22}$ ( $\mathrm{Y}_{7}$ : re-register regularly), $\mathrm{P}_{6}\left(\mathrm{X}_{23}\right.$ : fees), $\mathrm{P}_{24}\left(\mathrm{Y}_{9}\right.$ : active in study group), $\mathrm{P}_{23}$ ( $\mathrm{Y}_{8}$ : active in tutorials), $\mathrm{P}_{11}$ ( $\mathrm{X}_{42}$ : support from faculty), and $\mathrm{P}_{7}\left(\mathrm{X}_{31}\right.$ : website). 'Low Priority' is an indication that satisfaction and the degree of its importance are in the low category. The University should classify these aspects as 'the next' focus after concentrating on the critical points found in $\mathrm{Q}_{1}$ and $\mathrm{Q}_{2}$.

Finally, in $\mathrm{Q}_{4}$, five points are classified as 'Possible Overkill', viz. $\mathrm{P}_{3}\left(\mathrm{X}_{13}\right.$ : reputation), $\mathrm{P}_{10}\left(\mathrm{X}_{41}\right.$ : attention from staff), $\mathrm{P}_{5}\left(\mathrm{X}_{22}\right.$ : schedules $), \mathrm{P}_{9}\left(\mathrm{X}_{33}\right.$ : cleanliness $), \mathrm{P}_{20}\left(\mathrm{Y}_{5}\right.$ : general administration). 'Possible Overkill' indicates that the service quality provided is considered less important but respondents considered them as high in satisfaction. Here, attention to the attributes included can be less focused so that the University can save costs by redirecting them to take up vital points in $\mathrm{Q}_{1}$ and maintain crucial points in $\mathrm{Q}_{2}$.

Having positioned the variables and dimensions as they should be in relation to the quadrants based on IPA-CSI, we are now in the position to relate the loading factors of the model to observe the power of the relations of each variable involved under SEM (Figure 4) to work out the end results. 


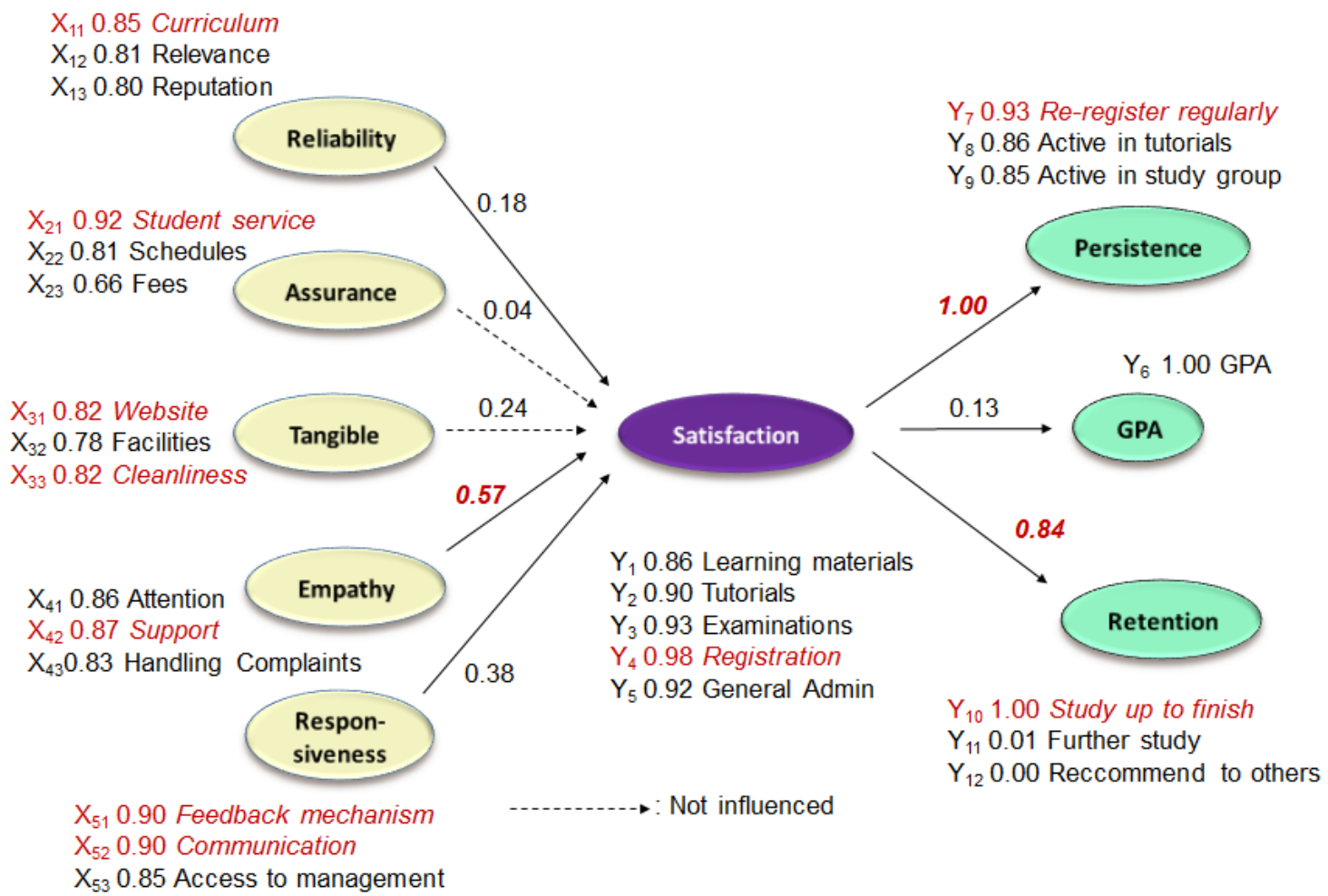

Figure 4 Loading factors of the model

Figure 4 shows the five foremost end results:

- The first is related to the three variables which directly influence satisfaction: (i) empathy $\left(\mathrm{X}_{4}=0.57\right)$, (ii) responsiveness $\left(\mathrm{X}_{5}=0.38\right)$ and (iii) reliability $\left(\mathrm{X}_{1}=0.18\right)$.

- The second finding relates to the ranks of the dimensions in empathy $\left(\mathrm{X}_{4}\right)$ : (i) support from the faculty $\left(\mathrm{X}_{42}=0.87\right)$, (ii) attention from staff $\left(\mathrm{X}_{41}=0.86\right)$ and (iii) handling complaints $\left(\mathrm{X}_{43}=0.83\right)$. The dimensions of responsiveness are: (i) feedback mechanism $\left(\mathrm{X}_{51}=0.90\right)$, (ii) communication $\left(\mathrm{X}_{52}=0.90\right)$ and (iii) access to management $\left(\mathrm{X}_{53}=0.85\right)$. The standings of the dimensions in reliability are: (i) curriculum $\left(X_{11}=0.85\right)$, (ii) relevance $\left(X_{12}=0.81\right)$ and (iii) reputation $\left(X_{13}=0.80\right)$.

- In the third finding, respondents put the order of satisfaction $(\mathrm{Y})$ from the provision of services: (i) registration $\left(\mathrm{Y}_{4}=0.98\right)$, (ii) examination $\left(\mathrm{Y}_{3}=0.93\right)$, (iii) general administration $\left(\mathrm{Y}_{5}=0.92\right)$, (iv) tutorial $\left(\mathrm{Y}_{2}=0.90\right)$ and $(\mathrm{v})$ learning materials $\left(\mathrm{Y}_{1}=\right.$ $0.86)$.

- The fourth result is associated with the power of relations between satisfaction (Y) and GPA $\left(\mathrm{Y}_{6}\right)$, persistence $\left(\mathrm{Y}_{7}, \mathrm{Y}_{8}\right.$ and $\left.\mathrm{Y}_{9}\right)$ and retention $\left(\mathrm{Y}_{10}, \mathrm{Y}_{11}\right.$ and $\left.\mathrm{Y}_{12}\right)$. Figure 4 clearly validates that satisfaction has a significant effect on persistence (1.00) and 
retention (0.84). However, satisfaction impinging on GPA is less (0.13) significant in comparison to persistence and retention.

- The fifth effect is on the dimensions of persistence, i.e. in order (i) re-register regularly $\left(\mathrm{Y}_{7}=0.93\right)$, (ii) active in tutorials $\left(\mathrm{Y}_{8}=0.86\right)$ and (iii) active in study group $\left(\mathrm{Y}_{9}=0.85\right)$; while for retention, only study up to the finish $\left(\mathrm{Y}_{10}=1.00\right)$ holds. 'Further study' $\left(\mathrm{Y}_{11}=0.11\right)$ and 'recommends to other' $\left(\mathrm{Y}_{12}=0.00\right)$ seem to be statistically excluded from the analysis. A further inquiry is required to discover why they are not valued yet by the respondents in this study.

Before moving to the final remarks, it is worthwhile to consider whether the result of using SEM was labelled as a 'good fit' category, so it is possible to assess the hypotheses and engender the loading factors of the model. The analysis showed that they were all considered a 'good fit' (Table 2), which means that the model is suitable - the conceptual and basic (operational) model in this research substantially and methodologically were aligned with each other.

Table 2 The goodness of fit of the model

\begin{tabular}{lcccc}
\hline Goodness of Fit & Cut-off Value & Results & Notes \\
\hline P-value & $\geq 0.05$ & 0.02 & $*$ \\
\hline RMR (Root Mean Square Residual) & $\leq$ & 0.05 or $\leq$ & 0.036 & Good Fit \\
\hline RMSEA (Root Mean Square Error of Measurement & $\leq 0.08$ & 0.041 & Good Fit \\
\hline GFI (Goodness of Fit) & $\geq 0.90$ & 0.91 & Good Fit \\
\hline AGFI (Adjusted Goodness of Fit Index) & $\geq 0.90$ & 0.94 & Good Fit \\
\hline CFI (Comparative Fit Index) & $\geq 0.90$ & 0.98 & Good Fit \\
\hline NFI (Norm Fit Index) & $\geq 0.95$ & 0.96 & Good Fit \\
\hline * To certain extent, it is acceptable as long as that is the only value under the \\
requirement.
\end{tabular}

\section{Concluding Remarks}

Delivering a quality service has become an important goal for higher education institutions (Athiyaman, 1997), including ODL institutions. The goal is to concurrently maintain the size of the student body and comply with student expectations. The use of IPA-CSI — as shown by Silva and Fernandes (2010) and Tileng, Wiranto and Latuperissa (2013) — has indicated the points of services which institutions should focus on and maintain, as well as those to which they might give less attention and even minimize resource spending.

The analysis of SEM showed that the University has to pay considerable attention to empathy, responsiveness and reliability as routes to satisfaction which lead to persistence and/or retention. While issues related to assurance and tangibility are not problematic at present, nevertheless assuring that procedures are improved and 
maintaining available facilities will augment the quality of services. Such developments will enhance satisfaction as previously highlighted by Parasuraman, Zeithaml and Berry (1988) and later elaborated by Tan and Kek (2004). Regrettably, the results do not yet show a significant correlation between satisfaction and GPA, and conducting further study in this area is very important.

Overall, the University administrators and faculty are advised to reflect on the aspects of satisfaction as a guide to persistence and/or retention to uphold its mission of making higher education open to all through flexible quality education.

\section{Acknowledgement}

I am grateful to both Professor Tian Belawati, the Rector of Universitas Terbuka, for her continuous support and Kristanti A. Puspitasari, $\mathrm{PhD}$, the Director of the Research and Community Services Institute of Universitas Terbuka for her permission for the research to be finally made possible.

\section{References}

Archambault, L.Z. (2008). Measuring service performance, student satisfaction and its impact on student retention in private, post-secondary institutions. Proceedings of the EDU-COM International Conference, Edith Cowan University Retrieved from http://ro.ecu.edu.au/ceducom/2).

Arokiasamy, A.R.A., \& Abdullah, A.G. (2012). Service quality and students' satisfaction at higher learning institutions. International Journal of Management and Strategy, 3(5), 1-16.

Athiyaman, A. (1997). Linking student satisfaction and service quality perceptions: The case of university education. European Journal of Marketing, 31(7), 528-540.

Bean, J. P. (1983). The application of a model of turnover in work organizations to the student attrition process. Review of Higher Education, 6, 129-148.

Bean, J. P. (1985). Interaction effects based on class level in an exploratory model of college student dropout syndrome. American Educational Research Journal, 22(1), 35-64.

Brown, R. M. (2006). Factors driving student satisfaction and retention in Australian universities: The importance of institutional image. Paper presented at the 20th Annual ANZ Academy of Management Conference, Rockhampton, 6-10 December 2006. 
Hanaysha, J.R.M., Abdullah, H. H., \& Waroka, A. (2011). Service quality and students' satisfaction at higher learning institutions: The competing dimensions of Malaysian universities' competitiveness. Retrieved from www.ibimapublishing.com/journals/JSAR/jsar.html).

Ilias, A., Hasan, H. F. A., \& Rahman, R. A. (2008). Student satisfaction and service quality: Any differences in demographic factors? International Business Research, 1(4), 131-143.

Kitcharoen, K. (2004). The IPA of service quality in administrative departments of private universities in Thailand. ABAC Journal, 24(3), 20-46.

Mailany, H. (2011). Study on the factors affecting student satisfaction in Bogor Agriculture University. Thesis, Bogor Agriculture University, Indonesia.

Martirosyan, N. M., Saxon, D. P., \& Wanjohi, R. (2014). Student satisfaction and academic performance in Armenian higher education. American International Journal of Contemporary Research, 4(2), 1-5.

Parasuraman, A., Zeithaml, V. A., \& Berry, L. L. (1988). SERVQUAL: A multiple-item scale for measuring consumer perception of SERVQUAL. Journal of Retailing, 64(1), 12-40.

Petruzzellis, L., D’Uggento, A. M., \& Romanazzi, S. (2006). Student satisfaction and quality of service in Italian universities. Managing Service Quality, 16(4), 349-364.

Roberts, J., \& Styron, R. Jr. (2009). Student satisfaction and persistence: Factors vital to student retention. AABRI, 1-18. Retrieved from http://www.aabri.com/manuscripts/09321.pdf).

Rojaz-Mendez, J. I., Vasquez-Paraga, A.Z., Kara, I., \& Cerda-Urrutia, A. (2009). Determinant of student retention in higher education: A tested relationship approach in Latin America. Latin American Business Review, 10, 21-39.

Sawitri, H. H., \& Sembiring, M. G. (2013).Visualizing impending features shaping persistence viewed by Universitas Terbuka students at Denpasar Regional Office. Paper presented at the 27th Annual Conference of AAOU, Islamabad, Pakistan,1-3 October 2013.

Sembiring, M.G. (2012). Determinants of students' loyalty at Universitas Terbuka. Paper presented at the 26th Annual Conference of AAOU, Chiba, Japan, 16-18 October 2012. 
Sembiring, M.G. (2014). Modeling determinants of student retention in distance education institutions. International Journal of Continuing Education \& Lifelong Learning, 6(2), 15-18.

Silva, F., \& Fernandes, O. (2010). Using importance-performance analysis in evaluating of higher education. International Conference on Education and Management Technology, (ICEMT 2010), Cairo, Egypt, 2-4 November 2010.

Singarimbun, M., \& Effendi, S. (1989). Metode penelitian survai. Jakarta: LP3ES.

Sugiyono, S. (2012). Metode penelitian kombinasi. Bandung: Penerbit Alfabeta.

Tan, K.C., \& Kek, S.W. (2004). Service quality in higher education using an enhanced SERVQUAL approach. Quality in Higher Education, 10(1), 17-24.

Tileng, M. Y., Wiranto, H. U., \& Latuperissa, R. (2013). Analysis of service quality using Servqual method and IPA in Population Department, Tomohon City, South Sulawesi. International Journal of Computer Applications, 70(19), 23-30.

Tinto, V. (1982). Limits of theory and practice in student attrition. The Journal of Higher Education, 53(6), 687-700.

Tinto, V. (1993). Leaving college: Rethinking the causes and cures of student attrition. (2nd Ed.). Chicago: University of Chicago.

Tinto, V. (1997). Classrooms as communities: Exploring the educational character of student persistence. The Journal of Higher Education, 68(6), 599-623.

Tjiptono, F., \& Chandra, G. (2011). Service, quality \& satisfaction. Yogyakarta: Penerbit Andi.

Universitas Terbuka. (2011). Strategic and operational planning of Universitas Terbuka 2011-2021. (Revised Version). Tangerang Selatan: Universitas Terbuka.

Wijayanto, S.H. (2008). Structural equation modeling - Lisrel 8.80. Yogyakarta: Penerbit Grahallmu. 